\title{
Practical Aspects of Obtaining and Applying Plant Antioxidant Complexes Based on Medicinal Herb Raw Materials
}

\author{
Ekaterina V. Pastushkova' *, Natalia V. Leiberova', Dmitry A. Karh'
}

${ }^{1}$ Ural State University of Economics, Ekaterinburg, Russian Federation, *e-mail: pas-ekaterina@yandex.ru

Keywords:

medicinal herb

raw materials;

antioxidant complex;

tea beverage

concentrate;

biologically active

substances;

antioxidants

\begin{abstract}
The article concerns the development of an antioxidant complex (AOC) based on medicinal herb raw materials (MHRM) obtained using mathematical modeling methods, considering the specifics of their functional purpose, and the study of its influence on the quality indicators of tea beverage concentrate (TBC). The research includes results of evaluating the developed AOC model quality, indicating high flavor characteristics and antioxidant properties. The authors developed 4 models of tea beverage concentrate using a computer program for the selection of food ingredients of an antioxidant orientation with regard to the organoleptic compatibility and antioxidant orientation. The article presents the production technology of TBC prototypes briefly. The researchers analyzed a control sample of a tea drink made according to a traditional recipe and developed models of tea beverage concentrates with the addition of an antioxidant complex. They revealed that the AOC introduction in the TBC: a) had a positive effect on organoleptic quality indicators due to a soft, harmonious taste with a pronounced tone of MHRM in taste and aroma; b) increased the amount of tanning substances, namely tannins by $28.0-85.0 \%$, flavonoids by an average of $24.8 \%$; c) antioxidant activity increased in $1.5-2$ times.
\end{abstract}

\section{Практические аспекты получения и применения растительных антиоксидантных комплексов на основе лекарственно-технического сырья}

\section{Е.В. Пастушкова ${ }^{1}$, Н.В. Лейберова ${ }^{1}$, Д.А. Карх ${ }^{1}$}

'уральский государственный экономический университет, г. Екатеринбург, Российская Федерация, *e-mail:pas-ekaterina@yandex.ru

Ключевые слова:

лекарственнотехническое сырье; антиоксидантный комплекс; концентрат чайного напитка;

\section{Реферат}

Статья посвящена вопросам разработки антиоксидантного комплекса (АОК) на основе лекарственно-технического сырья (ЛТС) с помощью методов математического моделирования, учитывающих специфику их функционального назначения, а также изучению его влияния на показатели качества концентратов чайного напитка. Представлены результаты оценки качества разработанных моделей антиоксидантных комплексов, свидетельствующие о их высоких вкусоароматических характеристиках и антиоксидантных свойствах. С помощью программы ЭВМ по подбору пищевых ингредиентов антиоксидантной направленности, учитывающей органолептическую 
биологически активные вещества; антиоксиданты совместимость и антиоксидантную направленность, разработаны четыре модели концентрата чайного напитка (КЧН). Кратко представлена технология производства опытных образцов КЧН. Проведен анализ контрольного образца чайного напитка, изготовленного по традиционной рецептуре, и на основе разработанных моделей его концентратов с добавлением растительного антиоксидантного комплекса. Установлено, что внесение АОК в КЧН: а) положительно влияет на органолептические показатели качества КЧН, обусловливая мягкий, гармоничный вкус с выраженным тоном ЛТС во вкусе и аромате; 6) повышает содержание дубильных веществ, а именно: танинов - на 28,0-85,0 \%, флавоноидов - в среднем на 24,8 \%; в) приводит к росту антиоксидантной активности в 1,5-2 раза.

Для цитирования: Пастушкова Е.В., Лейберова Н.В., Карх Д.А. Практические аспекты получения и применения растительных антиоксидантных комплексов на основе лекарственно-технического сырья // Индустрия nuтания|Food Industry. 2020. T. 5, № 4. C. 52-59. DOI: 10.29141/2500-1922-2020-5-4-8

Дата поступления статьи: 19 ноября 2020 г.

\section{Applicability}

Currently, one of the major medical and social problems associated with the population nutrition is the significant prevalence and steady growth of non-communicable diseases caused by antioxidant deficiency. The population health status indicated as the external and internal factors combination that affect the entire life. Recently, according to Rospotrebnadzor of the Russian Federation, there has been a deterioration in the environment (air pollution, radiation) quality and a deficit in the essential biologically active substances (BAS) consumption including an antioxidant series, which contributes to the development of some non-communicable diseases (NCDs), including those caused by antioxidant deficiency (AOD).

One of the most promising areas in the field of food and processing industry is the development of functional food products, including tea products.

To solve this problem a man is to develop antioxidant complexes based on available types of local medicinal herb raw materials. It is a source of natural antioxidants that help the human body to adapt to the effects of harmful environmental factors and to increase resistance. The antioxidant complex has a high content of biologically active substances that increase organism resistance to the external factors that lead to the non-communicable diseases caused by the antioxidant deficiency. The AOC use becomes more promising direction in several sectors of the economy, including processing, food and pharmaceutical industries $[1 ; 2]$.

The factors that shape the tea products quality include the most modern approaches to technology and raw materials. It is based on the modification of the ingredient composition and traditional food technologies using software that allows not only to design the composition and technological modes, but also to reduce unreasonable risks associated with the safety and economic feasibility of the developed food products. In this regard, the research relevance is to study the effect of plant antioxidant complexes on the tea products quality.

\section{Objects and Methods of the Research}

Models of antioxidant complexes and experimental samples of tea concentrates with antioxidant complexes added are the research objects.

Considering the specifics of MHRM functional purpose authors provided an AOC development algorithm, consisting of seven stages, conditionally divided into analytical and scientific-practical parts. Its implementation can occur both in parallel and sequentially (Fig. 1).

The authors developed recipe components of $A O C$ using linear programming methods [3], considering the matrix of functional orientation of medicinal herb raw materials. The AOC technology is following. Firstly, a man places dried vegetable raw materials in a blending drum (mode B2-ChKB-P1) and mixes it at a rotation speed of 4-5 rpm for 5-6 minutes. At the final stage of dosing and subsequent packaging, a man used a vertical packaging machine with a weight dispenser MDU-NOTIS-01M. This technology is aimed at obtaining a product with improved organoleptic characteristics, simplifying the technological process, and expanding the range of AOC based on the local MHRM.

The authors carried out determination of organoleptic, physical and chemical parameters in the AOC models and experimental samples of tea beverage concentrate using generally accepted standard and additionally developed methods.

The researchers determined:

- organoleptic indicators in the models of AOC and TBC using developed five-point scales based on the organoleptic indicator evaluation, which involves weighting coefficients for each pattern; 


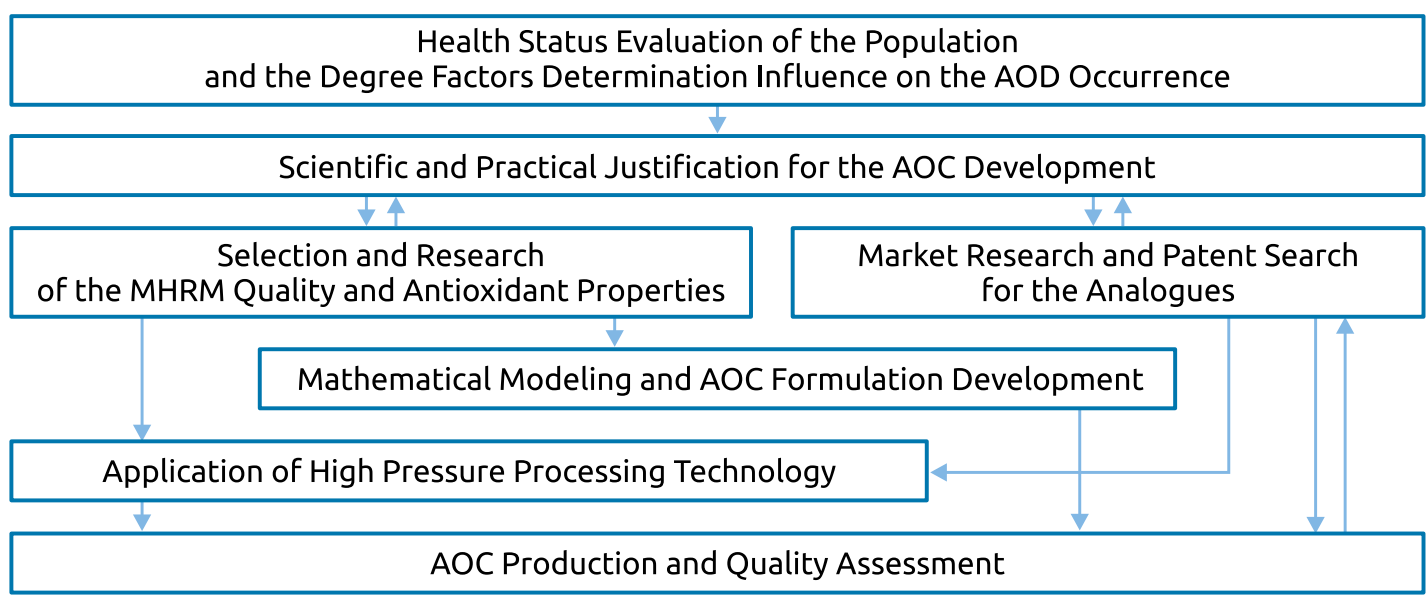

Fig. 1. Algorithm for the Antioxidant Complexes Development

Рис. 1. Алгоритм разработки антиоксидантных комплексов

- the mass fraction of moisture and water-soluble extractives in the $A O C$ in accordance with the GPM.1.5.3.0007.15

- the content of ascorbic acid, flavonoids and tannins using high-performance liquid chromatography (HPLC) with pre-column derivatization by OPA and FMOC agents in food products (Agilent 1260 Infinity II) ${ }^{2}$;

- the antioxidant activity in the studied samples of AOC and TBC according to the potentiometry method using the MPA-1 analyzer ${ }^{3}$;

A man run experimental tests in the 3-5-fold repetition using software tools and statistics methods for processing experimental data.

\section{Results and Its Discussion}

At the first stage, the authors developed AOC formulations applying mathematical modeling methods, considering the organoleptic compatibility and functional purpose specifics of each component with high flavor characteristics and antioxidant properties. They assessed the commodity quality (Table 1$)^{4}$.

\footnotetext{
${ }^{1}$ GOST 24027.2-80. Medicinal Raw Materials. Methods for Determining Humidity, Ash Content, Extractive and Tannic Substances, Essential Oil; GOST 6687.2-90. Refractometric Method for Determining the Content of Dry Substances. M.: Izd-vo Standartov, 1987. $12 \mathrm{p}$.

${ }^{2}$ OFS.1.2.3.0017.15. Metody Kolichestvennogo Opredeleniya Vitaminov [Methods of Quantitative Determination of Vitamins] Gosudarstvennaya Farmakopeya Rossiyskoy Federatsii. Ministerstvo Zdravookhraneniya Rossiyskoy Federatsii. XIII-ye Izdaniye. 2015 URL: http://docs².kodeks.ru/document/420324567

${ }^{3}$ Patent № 2235998. Method for Determining the Oxidant. Antioxidant Activity of Solutions / Brynina, Kh. Z; Ivanova, A.V. Patent Holder (Ural State University of Economics, LLC «Scientific and Production Innovation Enterprise «IVA». Date of Publication: 10.09.2004.

${ }^{4}$ Certificate of State Registration of Computer Programs № 2018611807. Software Package for Selecting Food Ingredients of Antioxidant Orientation / Pastushkova, E.V.; Grashchenkov, D.V.; Chugunova, O.V.; Zavorokhina, N.V.; Application № 2017660250; Received: 11.10.2017; Registered: 07.02.2018.
}

Considering the maximum permissible concentrations of substances in the $A O C$ the researchers determined its ingredient composition. They confirmed the optimal composition during the tasting: AOC had a transparent infusion, different intensity degree, pleasant specific herbal aroma and harmonious rich taste with a herbal tone of different specificity depending on the medicinal herb raw materials included. The aftertaste was short and pleasant.

The developed $\mathrm{AOC}$ formulations are the scientific basis for creating other food products with antioxidant properties. The antioxidant complex can be used in crushed or powdered form, participate in the quality formation of food products in which redox processes of fats oxidation or enzymatic oxidation with the participation of lipoxygenase predominate. Table 2 provides recommendations for the possible use of the AOC [4].

A man can use the developed $A O C$ models based on vegetable raw materials in production of:

- soft drinks and tea products. The AOC improves the organoleptic properties (taste, color), including beverages with low organoleptic properties; increases the biological value; improves technological properties;

- bakery products. A man can use AOC in powdered form as a recipe component in the baked bread manufacture, thereby characterizing new organoleptic (taste) and aesthetic (appearance) properties, and in crushed form for sprinkling the upper part or the product completely (products of low humidity, baguettes, crispbreads);

- confectionery products. The AOC in powdered form is a recipe component of flour confectionery products (gingerbread, biscuits) in order to increase the biological and physiological value due to the BAS, determining the functional orientation of the product; 


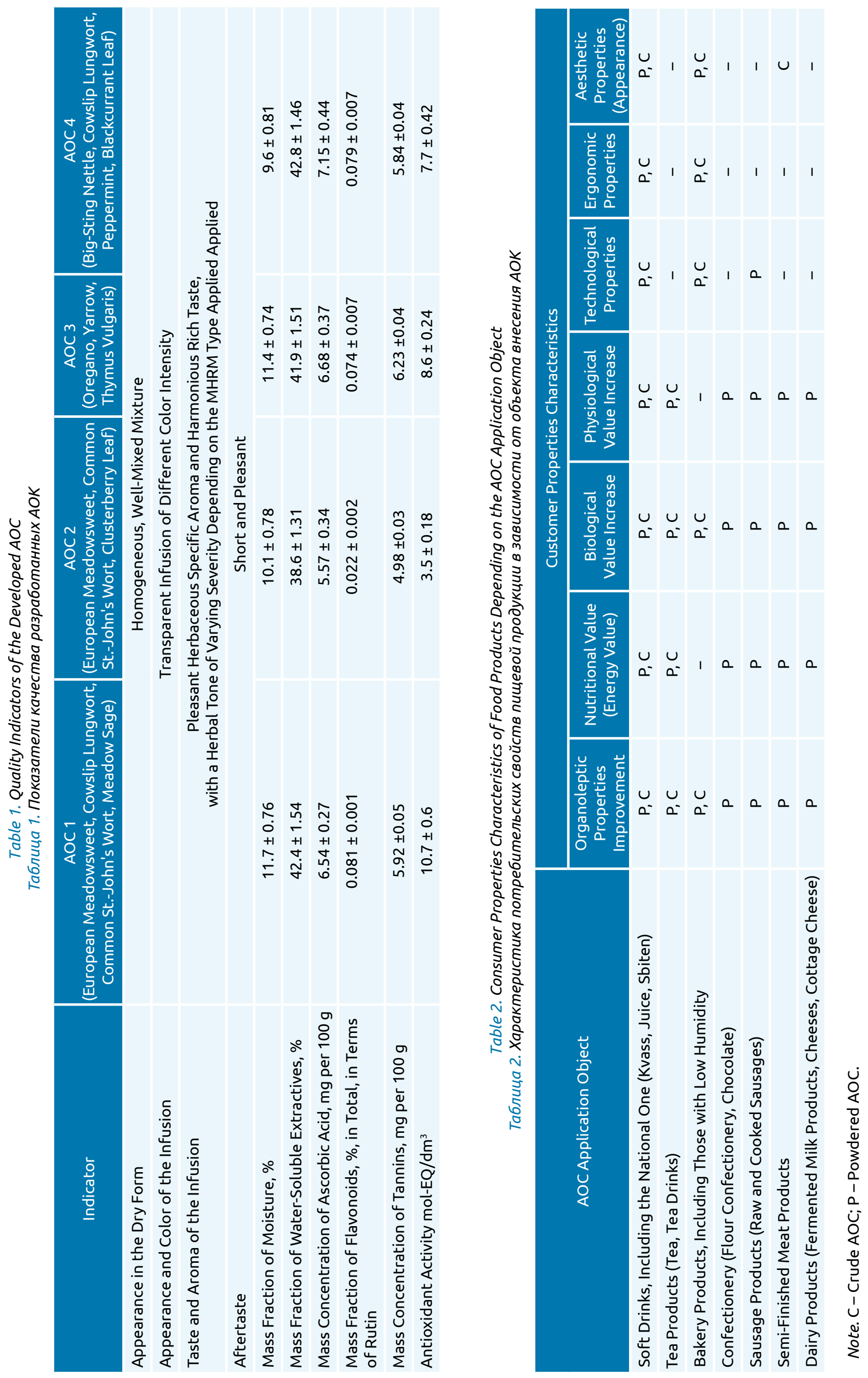


- sausage products. The AOC not only increases the nutritional value and taste specificity of the product, but also slows down the redox process or the enzymatic oxidation of fats with the lipoxygenase participation;

- semi-finished meat products. The AOC is a substitute for breading as a recipe component, thereby forming new organoleptic properties that increase the biological and physiological value;

- dairy products, namely as a recipe component used in the production of fermented milk beverages that have a high biological value due to the AOC composition; cottage cheese products (cottage cheese with $A O C$ ) resulting in improved organoleptic properties; dessert cheeses as breading $[3 ; 5]$.

At the next stage the researchers studied the AOC influence on the tea products quality using the tea beverage concentrate as an example. The main goal of the experimental TBC samples development is universality and mass consumption, pleasant organoleptic properties, naturalness and production simplicity. During the TBC ingredient composition development, the authors considered the complex use of medicinal herb raw materials included in the $A O C$, as well as its minor components study that provided an antioxidant orientation $[5 ; 6]$.

Small-leaved black Bayh tea was the recipe basis for modeling the TBC. It had a low cost (no more than 50 rubles per $100 \mathrm{~g}$ ) and low organoleptic characteristics - not enough rich and harmonious taste, undeveloped tea aroma.

The researchers developed four models of tea beverage concentrate on the basis of TBC formulations mathematical modeling, considering the organoleptic characteristics harmony of the components and the compositional compatibility of the therapeutic AOC action.

The PC certificate No. 2011614582 confirmed the novelty of technical solutions.
To select the TBC recipe components a man solved the following tasks:

- determined the antioxidant orientation (changing the chemical composition in order to increase the biological and consumer value due to the MHRM);

- chose the product form for ease of use;

- ensured the compatibility and naturalness of the selected components [1] (Table 3 ).

The production technology of tea beverage concentrate/syrup includes: dosing; preparing invert sugar syrup and extracting dry black tea and AOC; mixing prepared components in a blending tank $\mathrm{KM}-500$ for 10 min with further cooling in a cylindrical-conical tank TKT-40, allowing to get a readymade TBC with $t=(18 \pm 2){ }^{\circ} \mathrm{C}$; followed by bottling; capping in polyethylene bottles with a volume of $250 \mathrm{~cm}^{3}$ and marking.

At the final stage, the researchers studied the organoleptic, physical and chemical parameters of the developed TBC based on black Bayh tea with the addition of AOC (Fig. 2 and Table 4).

The results of the TBC tasting revealed that "excellent" category includes:

- model 1 (4.75 points) - has high organoleptic characteristics: soft, balanced, harmonious taste with a distinct tone of MHRM in taste and flavor; sweet aftertaste with a strong tinge of the meadow sage; a homogeneous, slightly viscous liquid;

- model 3 (4.75 points) - has high organoleptic characteristics: soft, balanced, harmonious taste with a pronounced floral and herbal tone in taste and aroma, due to the oregano content in the recipe; the aftertaste is soft, with a pronounced tone of the used MHRM; homogeneous liquid, slightly viscous;

- model 4 (4.75 points) - has a rich aroma of herbs in the taste and aroma, due to the peppermint content; the aftertaste is soft with mild bitterness, a homogeneous slightly viscous liquid.

Table 3. Ingredient Compositions of Tea Beverage Concentrates with the AOC Added, \% Таблица 3. Ингредиентные составы концентратов чайного напитка с добавлением АОК, \%

\begin{tabular}{|c|c|c|c|c|c|c|}
\hline $\begin{array}{c}\text { TBC } \\
\text { Model } \\
\text { Number }\end{array}$ & $\begin{array}{c}\text { AOC } \\
\text { Number } \\
\text { (Ingredient Composition) }\end{array}$ & $\begin{array}{c}\text { AOC } \\
\text { Dry } \\
\text { Extract }\end{array}$ & $\begin{array}{c}\text { Dry Extract } \\
\text { of Black } \\
\text { Bayh Tea }\end{array}$ & Sugar & $\begin{array}{c}\text { Prepared } \\
\text { Water }\end{array}$ & $\begin{array}{l}\text { Citric } \\
\text { Acid }\end{array}$ \\
\hline Model 1 & $\begin{array}{l}\text { AOC 1: European Meadowsweet, Cowslip Lungwort, } \\
\text { Common St.-John's Wort, Meadow Sage }\end{array}$ & 1.229 & 0.132 & 58.0 & 39.7 & 0.939 \\
\hline Model 2 & $\begin{array}{l}\text { AOC 2: European Meadowsweet, } \\
\text { Common St.-John's Wort, Clusterberry Leaf }\end{array}$ & 1.225 & 0.134 & 58.0 & 39.7 & 0.939 \\
\hline Model 3 & AOC 3: Oregano, Yarrow, Thymus Vulgaris & 1.219 & 0.142 & 58.0 & 39.7 & 0.939 \\
\hline Model 4 & $\begin{array}{l}\text { AOC 4: Big-Sting Nettle, Cowslip Lungwort, } \\
\text { Peppermint, Blackcurrant Leaf }\end{array}$ & 1.223 & 0.138 & 58.0 & 39.7 & 0.939 \\
\hline
\end{tabular}


Table 4. Physical and Chemical Indicators of the TBC Quality with the AOC Added

Таблица 4. Физико-химические показатели качества КЧН с добавлением АОК

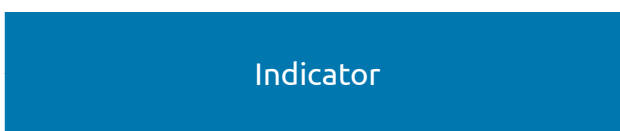

Mass Fraction of Dry Tea Extract, \%

Mass Fraction of Tanning Substances, \%, in Terms of Tannin

Mass Fraction of Flavonoids, \%, in Terms of Rutin

Antioxidant Activity, mol-EQ/g

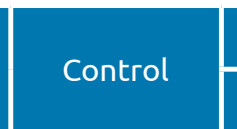

$22.0 \pm 0.13$

$4.2 \pm 0.02$

$0.155 \pm 0.008$

$4.24 \pm 0.03$
TBC Prototype

\begin{tabular}{|c|c|c|c|}
\hline \multicolumn{4}{|c|}{ TBC Prototype } \\
\hline Model 1 & Model 2 & Model 3 & Model 4 \\
\hline $35.2 \pm 0.4$ & $28.9 \pm 0.3$ & $26.8 \pm 0.3$ & $34.2 \pm 0.2$ \\
\hline $7.80 \pm 0.03$ & $6.15 \pm 0.03$ & $7.10 \pm 0.04$ & $5.40 \pm 0.03$ \\
\hline
\end{tabular}

$0.210 \pm 0.002$

$0.185 \pm 0.008 \quad 0.255 \pm 0.004 \quad 0.280 \pm 0.005$

$8.45 \pm 0.04$

$7.63 \pm 0.02$

$7.89 \pm 0.02$

$7.96 \pm 0.04$

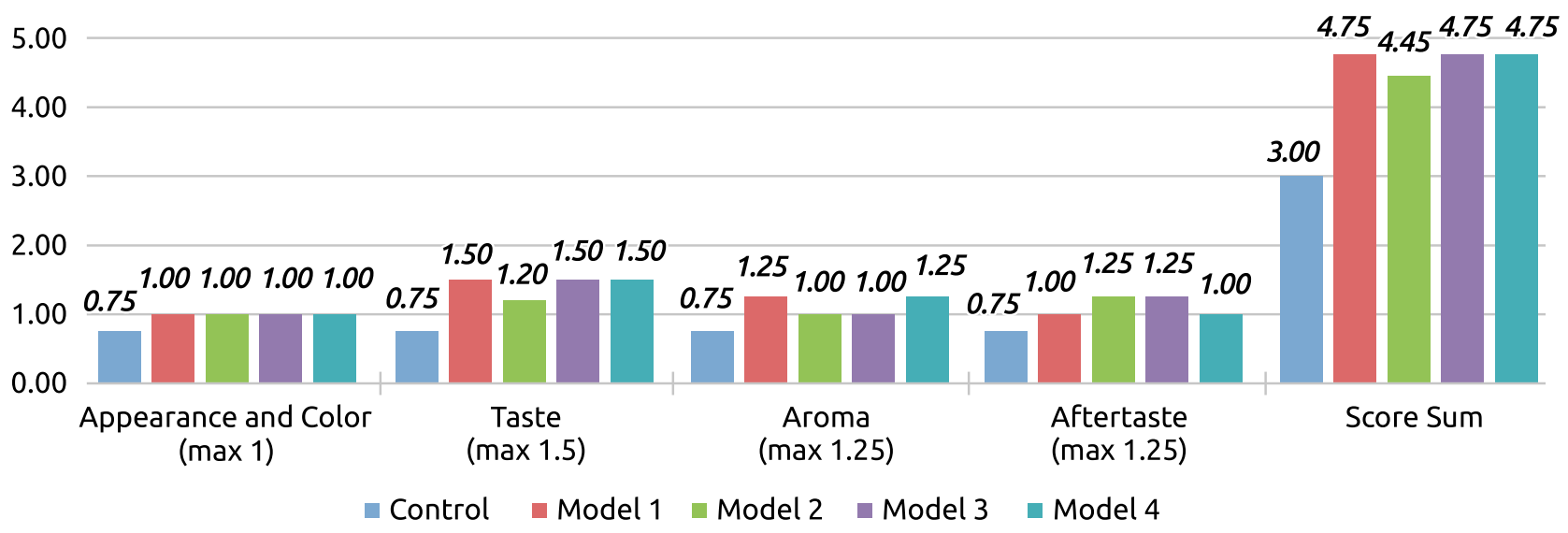

Fig. 2. Sensory Evaluation of the Developed TBC Models with the AOC Added, Score Puc. 2. Органолептическая оценка разработанных моделей КЧН с добавлением АОК, балл

The "good" category includes model 2 (4.45 points) of TBC, which has a soft harmonious tone of MHRM in taste and aroma, with a slight bitterness in the aftertaste, which is due to the content of the clusterberry leaf in the recipe; the liquid is homogeneous, slightly viscous.

Based on the analysis results of physical and chemical parameters of the developed TBC models, the authors revealed that the $A O C$ introduction increased the tanning substances amount, namely tannins by $28-85 \%$, flavonoids by an average $24.8 \%$, and antioxidant activity raise in 1.5-2 times.
The researchers conducted studies of the antioxidant activity (AOA) during the storage in accordance with the main provisions of MUK 4.2.1847-04 (Fig. 3).

Figure 3 shows that the AOA of the developed TBC decreases after 9 months of storage, due to the BAS content degression of the medicinal herb raw materials of the AOC. The greatest negative $d y-$ namics is in the TBC model with the addition of AOC № $4-21.8 \%$, the lowest - in the TBC model with the addition of AOC № 3-11.1\%.

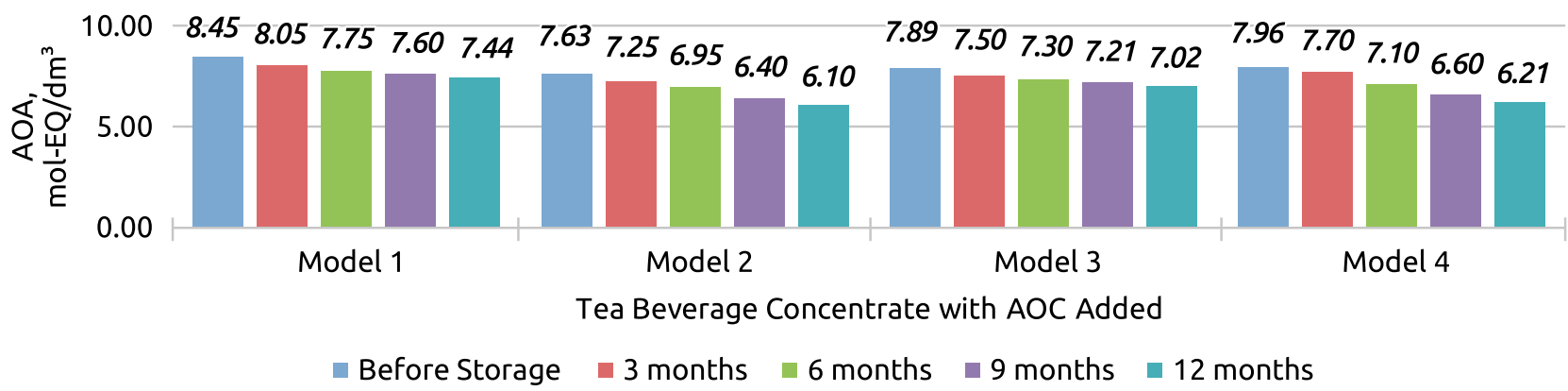

Fig. 3. AOA Dynamics of the TBC with the AOC Added during Storage, mol-EQ/dm ${ }^{3}$

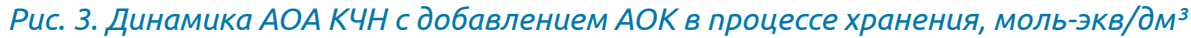




\section{Conclusion}

Using the method of mathematical modeling of the AOC, the researchers selected MHRM considering compatibility, flavor characteristics and functional orientation. They developed four recipe formulations, conducted the AOC quality assessment, and specified regulated indicators: organoleptic (appearance, color of infusion, aroma and taste) and chemical (weight fraction of moisture - not more than 12.0-18.0\%; weight fraction of water soluble - extractives - not less than $30.0 \%$; the amount per $100 \mathrm{~g}$ : vitamin C - 1.93-7.85 mg; bioflavonoids -192-764 g; tanning substances 0.05-0.16 mg).

A man developed recipes and technology for the production of tea beverage concentrates with the AOC added; gave a commodity research assessment of the developed products; and specified regulated quality indicators, conditions and storage periods at a temperature of $(18 \pm 2){ }^{\circ} \mathrm{C}$ and relative humidity $75.0 \%$ : tea beverage concentrate/syrup of the "Force of Nature" series is 12 months.

\section{Bibliography}

1. Arutyunyanc, A.A.; Salamova, N.A.; Lohov, R.E. Izuchenie Antiok sidantnoj Aktivnosti Aminokislot [Antioxidant Activity Study of Amino Acids]. Bashkirskij Himicheskij Zhurnal. 2012. Vol. 19, No. 1. Pp. 169-171.

2. Zavorohina, N.V.; Solovjeva, M.P.; Chugunova, O.V.; Pastushkova, E.V.; Fozilova, V.V. Rastitel'noe Syr'e Ural'skogo Regiona dlya Proizvodstva Bezalkogol'nyh Napitkov Antioksidantnoj Napravlennosti [Vegetable Raw Materials of the Ural Region for the Production of Soft Drinks of Antioxidant Orientation]. Pivo i Napitki. 2013. No. 3. Pp. 34-37.

3. Pastushkova, E.V.; Chugunova, O.V.; Tihonov, S.L. Sovremennye Podhody k Razrabotke Produktov dlya Profilaktiki Antioksidantnoj Nedostatochnosti [Modern Approaches to the Development of Products for the Prevention of Antioxidant Insufficiency Prevention]. Sovremennaya Nauka i Innovacii. 2019. No. 3. Pp. 95-106. DOI: 10.33236/2307-910X-2019-3-27-91-100

4. Pastushkova, E.V.; Chugunova, O.V.; Lejberova, N.V. Primenenie Metodov Linejnogo Programmirovaniya v Razrabotke Produktov Antioksidantnoj Napravlennosti [Application of Linear Programming Methods in the Development of Antioxidant Products Development] Sovremennye Problemy Nauki i Obrazovaniya. 2015. No. 1-1. Pp. 110.

5. Gorelikova, G.A. Nauchnoe Obosnovanie i Prakticheskie Aspekty Razrabotki i Ocenki Potrebitel'skih Svojstv Funkcional'nyh Bezalkogol'nyh Napitkov [Scientific Justification and Practical Aspects of Development and Evaluation of Consumer Properties of Functional Soft Drinks]: Avtoref. Dis. ... D-Ra Tekhn. Nauk: 05.18.15. Kemerovo, 2008. 45 p.

6. Bobreneva, I.V. Podhody k Sozdaniyu Funkcional'nyh Produktov Pitaniya [Approaches to the Functional Foods Production]: Mono grafiya. SPb.: IC “Intermediya”, 2012. 465 p.
The research shows that the substances content of phenolic nature-exogenous antioxidants flavonoids and tannins, as well as caffeine determines the antioxidant activity of the developed tea products and allows to recommend it as a functional product of an antioxidant orientation: the minor components amount identified in the experiment provides satisfaction of the daily need for tannins and flavonoids.

The experiment reveals that the developed models of tea products with the AOC added, considering the recommended level of the BAS consumption, meet up to $50.0 \%$ of the daily requirement for vitamin $C$, tannins and flavonoids.

In terms of the amount of heavy metals, radionuclides and microbiological indicators, the developed models of TBC with the AOC added during the entire storage period correspond to the TR CU 021/2011. Depending on the recipe components, the energy value ranges from 48 to $65 \mathrm{kcal}$ (201 to $272 \mathrm{~kJ}$ ).

\section{Библиографический список}

1. Арутюнянц А.А., Саламова Н.А., Лохов Р.Е. Изучение антиоксидантной активности аминокислот // Башкирский химический журнал. 2012. Т. 19, № 1. С. 169-171.

2. Заворохина Н.В., Соловьева М.П., Чугунова О.В., Пастушкова Е.В., Фозилова В.В. Растительное сырье Уральского региона для производства безалкогольных напитков антиоксидантной направленности // Пиво и напитки. 2013. № 3. С. 34-37.

3. Пастушкова Е.В., Чугунова О.В., Тихонов С.Л. Современные подходы к разработке продуктов для профилактики антиоксидантной недостаточности // Современная наука и инновации. 2019. № 3. C. 95-106. DOI: 10.33236/2307-910Х-2019-3-27-91-100.

4. Пастушкова Е.В., Чугунова О.В., Лейберова Н.В. Применение методов линейного программирования в разработке продуктов антиоксидантной направленности // Современные проблемы науки и образования. 2015. № 1-1. С. 110.

5. Гореликова Г.А. Научное обоснование и практические аспекты разработки и оценки потребительских свойств функциональных безалкогольных напитков: автореф. дис. ... д-ра техн. наук: 05.18.15. Кемерово, 2008. 45 c.

6. Бобренева И.В. Подходы к созданию функциональных продуктов питания: монография. СПб.: ИЦ «Интермедия», 2012. 465 с. 


\section{Information about Authors / Информация 06 авторах}

Pastushkova,

Ekaterina Vladimirovna

Пастушкова

Екатерина Владимировна

Тел./Phone: +7 (343) 283-10-59

E-mail:pas-ekaterina@yandex.ru

\section{Leiberova,}

Natalia Viktorovna

\section{Лейберова}

Наталия Викторовна

Тел./Phone: +7 (343) 283-10-59

E-mail:nleyberova@mail.ru

\section{Karh, \\ Dmitry Andreevich \\ Kapx \\ Дмитрий Андреевич \\ Тел./Phone: +7 (343) 283-13-33 \\ E-mail: ucheba@usue.ru}

Candidate of Technical Science, Associate Professor of the Merchandise and Expertise Department Ural State University of Economics 620144, Russian Federation, Ekaterinburg, 8 March St. / Narodnoy Voli St., 62/45

Кандидат технических наук, доцент кафедры товароведения и экспертизы Уральский государственный экономический университет 620144, Российская Федерация, г. Екатеринбург, ул. 8 Марта/Народной Воли, 62/45 ORCID: https://orcid.org/0000-0001-6992-1201

Candidate of Technical Science, Associate Professor of the Merchandise and Expertise Department Ural State University of Economics 620144, Russian Federation, Ekaterinburg, 8 March St. / Narodnoy Voli St., 62/45

Кандидат технических наук, дочент кафедры товароведения и экспертизы Уральский государственный экономический университет 620144, Российская Федерация, г. Екатеринбург, ул. 8 Марта/Народной Воли, 62/45 ORCID: https://orcid.org/0000-0002-9621-4489

Doctor of Economic Science, Professor of the Logistics and Commerce Department Ural State University of Economics 620144, Russian Federation, Ekaterinburg, 8 March St. / Narodnoy Voli St., 62/45

Доктор экономических наук, профессор кафедры логистики и коммерции Уральский государственный экономический университет 620144, Российская Федерация, г. Екатеринбург, ул. 8 Марта/Народной Воли, 62/45 ORCID: https://orcid.org/0000-0003-2140-7638 